\title{
PENGARUH MOTIVASI KERJA TERHADAP KEPUASAN KERJA \\ PENYULUH PERIKANAN DI BADAN KETAHANAN PANGAN \\ PELAKSANA PENYULUHAN PERTANIAN PERIKANAN DAN \\ KEHUTANAN (BKP5K) KABUPATEN BOGOR.
}

\author{
oleh \\ Sobariah dan Ani Leilani \\ Dosen Jurusan penyuluhan Perikanan Sekolah tinggi Perikanan
}

\begin{abstract}
ABSTRAK
Pengaruh Motivasi Kerja Terhadap Kepuasan Kerja Penyuluh Perikanan di Badan Ketahanan Pangan Pelaksana Penyuluhan Pertanian Perikanan dan Kehutanan (BKP5K) Kabupaten Bogor.

Dalam upaya meningkatkan kepuasan kerja pegawai fungsional pada Badan Pelaksana Penyuluhan Pertanian Perikanan dan Kehutanan, terdapat berbagai faktor yang perlu mendapat perhatian, antara lain motivasi dari para pegawai yang bekerja di instansi tersebut maupun mengembangkan karier yang dirasakan oleh pegawai dalam melaksanakan pekerjaannya. akan dapat meningkatkan kepuasan kerja. Tingginya motivasi dari para pegawai di instansi tersebut akan meningkatkan kepuasan kerja sehingga berdampak positif dalam lingkungan eksternal instansi yakni peningkatan kepercayaan masyarakat dalam memberikan penyuluhan maupun transfer teknologi di bidang pertanian.umumnya dan perikanan khususnya.

Berdasarkan latar belakang tersebut maka akan dilakukan penelitian mengenai MOTIVASI dan KEPUASAN KERJA PENYULUH. Tujuan penelitian ini adalah untuk mengetahui sejauhmana pengaruh motivasi kerja terhadap kepuasan kerja penyuluh di Badan Ketahanan5) Kabupaten Bogor.

Penelitian ini menggunakan metode deskriptif eksploratif Berdasarkan penelitian yang dilakukan mengenai pengaruh Motivasi terhadap Kepuasan Kerja pada Badan Ketahanan Pangan Pelaksana Penyuluhan Pertanian Perikanan dan Kehutanan, hasil pengolahan data terhadap variabel bebas Motivasi $\left(\mathrm{X}_{1}\right)$ dan variabel terikat Kepuasan Kerja (Y) dapat diambil beberapa kesimpulan sebagai berikut :

1. Hasil uji t variabel Motivasi $\left(\mathrm{X}_{1}\right)$ terhadap Kepuasan Kerja (Y) menunjukkan bahwa nilai $t_{\text {hitung }}$ sebesar 5,301 dan $t_{\text {tabel }}$ sebesar 1,96 pada level significants 0,05 dan probabilitas 0,000 . Hal ini berarti $\mathrm{t}_{\text {hitung }}=5,301>\mathrm{t}_{\text {tabel }}=1,96$, maka $\mathrm{H}_{0}$ ditolak dan $\mathrm{H}_{\mathrm{a}}$ diterima, berarti terdapat pengaruh Motivasi $\left(\mathrm{X}_{1}\right)$ terhadap Kepuasan Kerja (Y) pada Badan Ketahanan Pangan Pelaksana Penyuluhan Pertanian Perikanan dan Kehutanan.

2. Koefisien korelasi Motivasi $\left(\mathrm{X}_{1}\right)$ terhadap Kepuasan Kerja (Y) pada Badan Ketahanan Pangan Pelaksana Penyuluhan Pertanian Perikanan dan Kehutanan adalah 0,892 sehingga diperoleh nilai koefisien determinasi sebesar 0,795 atau $79,5 \%$. Hal ini berarti bahwa faktor-faktor lain di luar yang tidak diteliti namun berpengaruh juga adalah sebesar $20,5 \%$.
\end{abstract}

Kata kunci : aktivitas, kinerja, penyuluh perikanan 
PENDAHULUAN

\section{Latar Belakang Penelitian}

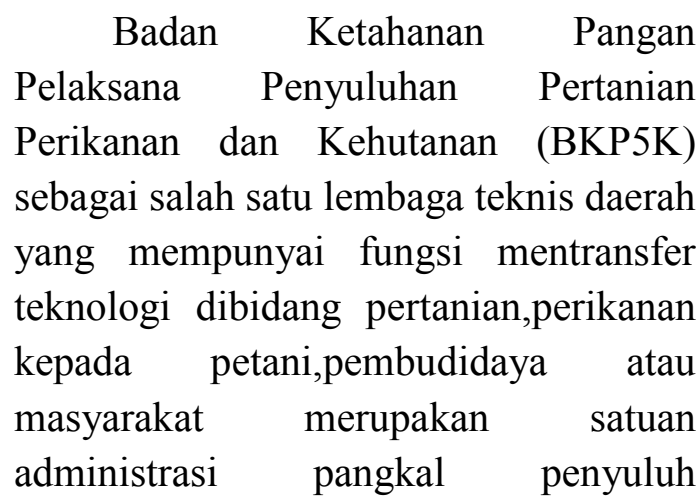
pertanian, perikanan. kinerja penyuluh perikanan sebagai ujung tombak pembangunan perikanan sangat dipengaruhi oleh berbagai faktor diantaranya adalah kepuasan kerja.

Sebagai lembaga teknis daerah yang sebagian besar pegawainya adalah pegawai fungsional dengan jenjang kenaikan pangkatnya didasarkan pada pencapaian angka kredit tertentu untuk dapat dinaikkan satu tingkat lebih tinggi.

Untuk dapat mencapai angka kredit (kredit Poin) tertentu pegawai fungsional yang berada di BKP5K harus melaksanakan berbagai kegiatan dengan kriteria dan persyaratan tertentu sesuai dengan jenjang pangkat, golongan maupun jabatan fungsionalnya. Dengan semakin meningkatnya aktivitas yang dilakukan maka idealnya kenaikan pangkat pegawai fungsional akan semakin cepat.

Kualitas pelaksanaan penyuluhan oleh pegawai fungsional yang ada di BKP5K sangat dipengaruhi oleh kemampuan tenaga penyuluh sebagai pembawa misi pemerintah khususnya dalam bidang transfer teknologi kepada para petani, pengalaman dan lamanya bekerja tidaklah cukup untuk melakukan perubahan di sektor pertanian umumnya, khususnya perikanan, karena dengan semakin derasnya arus globalisasi kemampuan lain seperti latar belakang pendidikan yang memadai, kompetensi, dan penguasaan teknologi informasi serta kepuasan kerja akan sangat mempengaruhi kinerja para penyuluh perikanan,hal ini sesuai dengan ketentuan yang berlaku yaitu dengan mengacu kepada surat keputusan Menteri Penertiban Aparatur Negara No 73 tahun 2004 tentang Jabatan Fungsional Penyuluh dan angka kreditnya dimana selain pengaturan angka kredit komulatif yang harus dipenuhi juga pangkat maksimal yang dapat dicapai sesuai dengan jenjang pendidikan terakhir penyuluh. klasifikasi tersebut salah satunya didasari oleh tingkat pendidikan formal.

Begitu pula halnya dengan kepuasan kerja yang dirasakan para pegawai dalam melaksanakan pekerjaannya juga akan dapat meningkat. Tingginya motivasi dari para pegawai di instansi tersebut akan meningkatkan kepuasan kerja sehingga berdampak positif dalam lingkungan eksternal instansi yakni peningkatan kepercayaan masyarakat dalam memberikan penyuluhan maupun transfer teknologi di bidang perikanan. Kepuasan kerja merupakan sekumpulan perasaan bersifat dinamik, dapat naik dan turun dengan cepat sehingga perasaan pekerja terhadap organisasi perlu diperhatikan secara berkesinambungan.

Selama ini kepuasan kerja selalui dikaitkan dengan penampilan kerja seorang pegawai. Sedangkan faktor faktor yang biasanya digunakan untuk mengukur kepuasan kerja seorang 
pegawai antara lain : (a) isi pekerjaan, penampilan tugas pekerjaan yang aktual dan sebagai kontrol terhadap pekerjaan, (b) supervisi), (c) organisasi dan manajemen, (d) kesempatan untuk maju, (e) gaji dan keuntungan dalam bidang finansial, (f) rekan kerja dan kondisi. Menurut pemikiran tradisonal, penampilan kerja berhubungan dengan kepuasan kerja. Sesuai yang dikemukakanBarnardin (1962:108) mengatakan bahwa : " The complexity of the relationship in any group increases with great rapidity as the number of persons in the group increases.

\section{Identifikasi Masalah}

Dari uraian latar belakang diatas maka dapat diidenebut maka akan dilakukan penelitian mengenaitifikasi masalah sebagai berikut :

a. Apakah tingkat pendidikan formal pegawai fungsional (penyuluh) perikanan berpengaruh terhadap kepuasan kerja penyuluhdi Kabupaten Bogor

b. Apakah motivasi pegawai fungsional penyuluh pertanian berpengaruh terhadap kepuasan kerja penyuluhdi Kabupaten Bogor

c. Apakah tingkat pengetahuan dan kemampuan pegawai fungsionalberpengaruh terhadap kepuasan kerja penyuluh perikanan di Kabupaten Bogor

d. Apakah masa kerja pegawai fungsional berpengaruh terhadap kepuasan kerja penyuluhperikanan di Kabupaten Bogor

e. Apakah pangkat maksimal,usia pensiun penyuluh perikanan sesuai tingkat pendidikan formal

f. Apakah kepuasan kerja penyuluh pertanian dipengaruhi oleh motivasi g. Apakah kepemimpinan berpengaruh terhadap kepuasan kerja penyuluhdi Kabupaten Bogor

h. Apakah budaya organisasi berpengaruh terhadap kepuasan kerja penyuluh perikanan di Kabupaten Bogor

\section{Batasan dan Rumusan Masalah Batasan Masalah}

Secara umum kepuasan kerja dipengaruhi oleh banyak hal antara lain motivasi pegawai, kepemimpinan, kreativitas, disiplin kerja, fasilitas tempat kerja, iklim kerja dan sikap profesionalitas, pengetahuan akan pekerjaan dan etika kerja.

Motivasi kerja dari para pegawai menjadi faktor pendukung utama dalam terlaksananya kepuasan kerja karena seseorang yang telah termotivasi dalam melakukan suatu pekerjaan akan senantiasa menciptakan kreativitas dan inovasi baru guna mendukung optimalisasi kepuasan dimana ia bekerja. Selain itu Salah satu faktor yang berperan sangat penting dalam kepuasan kerja. yang tinggi seorang pegawai akan memiliki dorongan dari dalam diri yang kuat untuk melakukan pekerjaan yang merupakan tanggung jawabnya. Kepuasan kerja semakin terasa bila lingkungan kerja memberi dukungan positif terhadap rencana dan pelaksanaan kerja seseorang yang bisa terwujud apabila terdapat atau terjalin komunikasi yang baik di antara sesama rekan kerja dan pimpinan.Hal ini senada yang dikatakan oleh Buchari Zainun (1984:22-23) sebagai berikut :yang pertamadisebut "Policy makers" atau pembuat kebijaksanaan.barangkali dapat disebut pegawai-pegawai atau pejabatpejabat pimpinan atau " manajerial employers",ketiga yaitu kelompok 
pekerja-pekerja atau pegawai-pegawai rendahan. Dalam istilah asingnya sering disebut pegawai "rank and file".

Kepuasan kerja akan semakin terasa bila iklim kerja memberikan dukungan positif. Iklim kerja yang kondusif sangat diperlukan agar pegawai dapat bekerja dengan tenang dan nyaman. Iklim kerja yang kondusif akan memberi semangat dan rangsangan pegawai untuk bekerja lebih maksimal tanpa ada rasa takut dan tertekan. Dengan kondisi semacam ini memungkinkan setiap pegawai untuk secara maksimal mengaktualisaikan dirinya dalam bekerja. Keadaan ini semakin menunjang pegawai untuk bekerja lebih produktif.

Untuk lebih memfokuskan penelitian pada variabel - variabel penelitian maka perlu dilakukan pembatasan masalah. Selain itu, pembatasan masalah dilakukan karena keterbatasan yang dimiliki, khususnya yang terkait dengan dana, waktu dan tenaga yang tersedia, penelitian ini hanya akan menelaah tiga faktor saja yaitu (1) motivasi (2) pengembangan karier dan (3) kepuasan kerja. Penetapan ketiga faktor ini didasarkan atas berbagai alasan antara lain kepuasan kerja tidak akan terwujud dengan baik tanpa didukung oleh motivasi yang tinggi dan pengembangan karier para pegawainya.

\section{Rumusan Masalah}

Berangkat dari paparan di atas dan untuk lebih memfokuskan masalah yang akan digali, maka masalah yang akan dibahas dalam penelitian ini dirumuskan dalam bentuk pernyataan penelitian sebagai berikut :
1. Seberapa besar pengaruh motivasi kerja terhadap kepuasan kerja penyuluh pertanian

2. Seberapa besar pengaruh pengembangan karier terhadap kepuasan kerja penyuluh pertanian

3. Seberapa besarpengaruh motivasi kerja dan pengembangan karier secara bersama-sama terhadap kepuasan kerja penyuluh pertanian

\section{Maksud dan Tujuan Penelitian \\ Maksud Penelitian}

1. Secara umum, penelitian ini dimaksudkan untuk dapat melahirkan dan mengembangkan proposisi proposisi maupun konsep - konsep yang terkait dengan Pengembangan karier penyuluhpertanian, Di samping itu penelitian ini juga dimaksudkan untuk mengembangkan sumberdaya manusia sehingga dapat dijadikan dasar dalam pengembangan teori teori yang terkait secara operasional.

2. Secara praktis, penelitian ini bertujuan mencari model implementasi yang tepat dalam memberdayakan dan meningkatkan kualitas pembinaan pegawai oleh Badan Pelaksana Penyuluhan Pertanian Perikanan dan Kehutanan bagi penyuluh pertanian sehingga kinerjanya dapat meningkat

\section{Tujuan Penelitian}

Tujuan penelitian adalah untuk:

Mengetahui pengaruh motivasi pegawai (penyuluh) terhadap kepuasan kerja penyuluh perikanan di BKP5K Kab. Bogor.

\section{Kegunaan Penelitian}

1. Secara teoritis dan akademis hasil penelitian ini diharapkan dapat memberikan kontribusi pemikiran bagi pengembangan ilmu pengetahuan khususnya yang berkaitan dengan kepuasan kerja penyuluh 
2. Sedangkan secara praktis diharapkan penelitian ini dapat menjadi bahan masukan bagi BKP5K Kab.Bogor dalam pengembangan kualitas layanan penyuluhan dalam rangka pengembangan instansi untuk menjawab tantangan di bidang Penyuluhan .

\section{Motivasi Kerja}

Faktor-faktor yang berperan sebagai motivator terhadap pegawai, yakni memuaskan dan mendorong orang untuk bekerja baik, terdiri dari :

- Keberhasilan pelaksanaan (achievement)

- Pengakuan (recognition)

- Pekerjaan itu sendiri (the work itself)

- Tanggungjawab (responcibilities)

- Pengembangan (advancement)Budi W.Soetjipto..(et.al). 2002.

Konsepsi motivasi mempunyai peranan penting bagi seseorang penanggung jawab dalam satuan-satuan organisasi untuk menggerakkan, mengerahkan dan mengarahkan segala daya dan potensi tenaga kerja yang ada ke arah pemanfaatan yang paling optimal sesuai dengan potensi dan dalam batas-batas kemampuan manusia dengan bantuan sarana-sarana dan fasilitas lainnya. Bantuan sarana dan fasilitas ini berupa alat-alat, uang, material dan metode..

Untuk menentukan cara, alat dan sarana motivasi yang tepat agar benarbenar mampu memberi kepuasan kepada manusia dengan memenuhi kebutuhankebutuhannya, maka terlebih dahulu perlu diadakan pengelompokan manusia dan anggota-anggota organisasi. Secara luas pengelompokan anggota organisasi dapat didasarkan kepada sifat struktural dan fungsionalnya orang-orang dalam organisasi.
Hal ini sebagaimana dikemukakan oleh Mason Haire (1959:187) yang menyatakan "one area of motivational studies is surprisingly lacking - the study of motivation of management".

\section{Kepuasan Kerja}

Kepuasan menggambarkan suatu konsep individu dan juga menggambarkan evaluasi atas suatu keadaan internal afektif terhadap hasil hasil yang diinginkan yang berasal dari suatu pekerjaan.

Di sini dapat dilihat bahwa kepuasan kerja bukan merupakan faktor kausal. Bagi institusi kerja, yang lebih penting adalah kepuasan kerja yang berkaitan dengan produktivitas dan kinerja pegawainya sebagai faktor kontribusi bagi derajat kinerja, walaupun kinerja sebenarnya dapat pula diimplementasikan sebagai penyebab kepuasan kerja.

\section{Adapun kerangka pemikiran}

penelitian adalah untuk mengetahui:

- Pengaruh motivasi terhadap Kepuasan Kerja penyuluh perikanan.

Motivasi $\left(\mathrm{X}_{1}\right)$ sebagai variabel bebas pertama adalah skor yang diperoleh dari pengukuran dengan menggunakan angket yang diukur dengan (1) Dimensi pertama adalah dimensi dorongan diri yang terdiri dari indikator - indikator antara lain dorongan dari diri sendiri, yaitu dorongan dari seseorang untuk melakukan suatu tindakan agar dapat memperoleh hasil yang lebih baik, baik untuk dirinya sendiri lingkungan kerjanya maupun lembaga dimana ia bekerja dorongan dari lingkungan, yaitu dorongan untuk melakukan sesuatu yang lebih baik dikarenakan lingkungan 
dimana ia bekerja menyenangkan dan sesuai dengan harapannya, dan indikator lainnya yaitu penghargaan, dimana hasil pekerjaan yang dilakukannya dihargai baik oleh pimpinan, maupun teman kerjanya. Sedangkan dimensi yang kedua,(2) adalah dimensi pengakuan yang terdiri dari indikator - indikator kebanggan terhadap pekerjaan yaitu ia akan merasa bangga apabila dapat menyelesaikan pekerjaannya tepat waktu, sesuai dengan arahan pimpinan maupun aturan-aturan yang ditetapkan ,indikator selanjutnya adalah kebanggan terhadap institusi yaitu ia merasa bangga bekerja pada institusi/lembaga tersebut dan senantiasa berusaha melakukan yang terbaik untuk institusi dimana ia bekerja, dan indikator kebanggan terhadap hasil kerja , yaitu ia akan merasa bangga apabila hasil pekerjaannya dapat diterima oleh pimpinan maupun teman sekerjanya.Luthans

mengemukakan bahwa kepuasan kerja pada dasarnya merujuk pada seberapa besar seorang pegawai menyukai pekerjaannya. Sementara Stephen P.Robbins (1994:417) mengungkapkan bahwa kepuasan kerja adalah sikap umum pekerja tentang pekerjaan yang dilakukan.

Dengan demikian diduga motivasi kerja mempunyai pengaruh terhadap kepuasan kerja penyuluh perikanan

\section{Hipotesis}

Dari uraian diatas maka dapat dikemukakan hipotesis sebagai berikut;Diduga terdapat pengaruh motivasi pegawai fungsional (penyuluh) terhadap Kepuasan kerja penyuluh

\section{Desain Penelitian}

Tujuan penelitian ini adalah untuk mengetahui apakah motivasi berpengaruh terhadap kepuasan kerja penyuluh perikanan pada Badan Ketahan Pangan dan Pelaksana Penyuluhan Pertanian Perikanan dan Kehutanan, dengan mengkaji variabel 1 bebas yaitu Motivasi $\left(\mathrm{X}_{1}\right)$ dan serta satu variabel terikat yaitu Kepuasan Kerja penyuluh pertanian (Y).

Penelitian ini menggunakan metode deskriptif eksploratif yang bertujuan memberikan gambaran tentang masing - masing variabel dan menggali keterkaitan variabel tersebut dengan cara menganalisis pengaruh variabel bebas terhadap variabel terikat. Pola pengaruh yang dikaji dalam penelitian ini direpresentasikan pada konstelasi masalah sebagaimana pada gambar 5 .

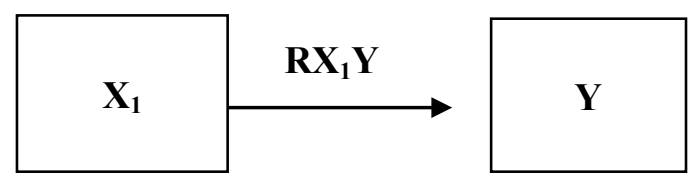

Gambar 5. Desain Penelitian

Y : Kepuasan Kerja

$\mathrm{RX}_{1} \mathrm{Y}$ : Parameter Struktural

Pengaruh $\mathrm{X}_{1}$ terhadap $\mathrm{Y}$

Tempat dan Waktu Penelitian

Penelitian tentang Pengaruh Motivasi dan Pengembangan Karier terhadap Kepuasan Kerja Penyuluh akan dilaksanakan di Badan Ketahanan Pangan dan Pelaksana Penyuluhan Pertanian Perikanan dan Kehutanan (BKP5K) kabupaten Bogor. 


\section{Populasi dan Sampel}

Populasi penelitian ini adalah seluruh penyuluh yang bekerja pada Badan Ketahan Pangan dan Pelaksana Penyuluhan Pertanian Perikanan dan Kehutanan baik sebagai pegawai tetap maupun pegawai kontrak yang berjumlah 209 orang terdiri dari pegawai tetap berjumlah 109 orang dan pegawai kontrak berjumlah 100 orang, dengan memperhatikan populasi yang homogen maka teknik sampling yang digunkanan adalah simple random sampling (sampel acak sederhana) yang merupakan bagian dari propability sampling

Selanjutnya penulis mencoba menetapkan jumlah sampel yang diambil dalam penelitian ini sebanyak 51 orang, dengan mengacu pada metoda isaac dan Michel dengan tingkat kesalahan $5 \%$, dengan menggunakan rumus Slovin (sampel kecil),dengan rumus sebagai berikut :

$$
\mathrm{n}=\frac{\mathrm{N}}{\mathrm{N}(\mathrm{a})^{2}+1}
$$

$\mathrm{N}=$ populasi

$\mathrm{n}=$ sampel

$\mathrm{a}=$ tingkat signifikasi $(0,05)$

dimana dari hasil penghitungan diperoleh data tabel untuk jumlah sampel 109 orang adalah 35, sedangkan untuk pegawai kontrak yaitu sebanyak 100 orang diperoleh data tabel 16, dengan demikian jumlah sampelnya sebagai berikut :

-. Pegawai tetap :

35 Orang

- Pegawai kontrak 16 Orang

\subsection{Definisi Variabel Penelitian} Motivasi Kerja

a. Difinisi Konseptual

b. Difinisi Operasional

Motivasi $\left(\mathrm{X}_{1}\right)$ sebagai variabel bebas pertama adalah skor yang diperoleh dari pengukuran dengan menggunakan angket yang diukur dengan (1) dimensi pertama adalah dimensi dorongan diri yang terdiri dari indikator - indikator antara lain dorongan dari diri sendi.

Kisi-Kisi indikator Penelitian

\begin{tabular}{|c|c|c|c|}
\hline No & Variabel & Dimensi & Indikator \\
\hline 1. & Motivasi & $\begin{array}{l}\text { a. Dorongan diri } \\
\text { b. Kebanggaan }\end{array}$ & $\begin{array}{l}\text { 1. Dorongan dari diri sendiri } \\
\text { 2. Dorongan dari lingkungan } \\
\text { 3. Penghargaan } \\
\text { 1. Terhadap pekerjaan } \\
\text { 2. Terhadap institusi } \\
\text { 3. Terhadap hasil kerja }\end{array}$ \\
\hline 2 & $\begin{array}{l}\text { Kepuasan } \\
\text { Kerja }\end{array}$ & $\begin{array}{l}\text { a. Lingkungan } \\
\text { b. Pendapatan }\end{array}$ & $\begin{array}{l}\text { 1. Pengakuan } \\
\text { 2. Tanggungjawab } \\
\text { 3. Budaya kerja } \\
\text { 1. Kompensasi } \\
\text { 2. Insentif }\end{array}$ \\
\hline
\end{tabular}

Tabel 1. Kisi-kisi Indikator Instrumen 


\section{Instrumen Penelitian/Teknik}

Pengumpulan Data

1. Studi Kepustakaan

2. Kuesioner dengan membuat

Pertanyaan -2. Adapun peringkat nilai pada jawaban yang dipilih ialah :

Sangat setuju (SS)

Setuju (S)

Kurang Setuju (KS)

Tidak Setuju (TS)

Sangat Tidak Setuju (STS)

\section{Rencana Analisis Data}

\section{Analisis Statistik Deskriptif Data}

Untuk mengetahui setiap variabel penelitian diperlukan analisis sebagai berikut;

Semua data dari hasil penyebaran angket ini diberi skor dan dianalisis dengan menggunakan uji statistik. Teknik analisis data yang digunakan dalam penelitian ini adalah teknik korelasi dan regresi, yaitu dengan korelasi sederhana untuk menentukan hubungan masing-masing variabel $\mathrm{X}$ dan $\mathrm{Y}$, regresi sederhana untuk menentukan kontribusi masing-masing variabel $\mathrm{X}$ dengan $\mathrm{Y}$, korelasi ganda untuk menentukan hubungan variabel $\mathrm{X}_{1}, \mathrm{X}_{2}$ secara bersama-sama terhadap variabel Y, dan regresi ganda untuk menentukan kontribusi variabel $\mathrm{X}_{1} \mathrm{X}_{2}$ secara bersama-sama terhadap variabel $\mathrm{Y}$.

Adapun rumus yang digunakan adalah sebagai berikut:

1. Korelasi Sederhana, dengan rumus :

$$
r_{x y} \frac{n \sum X Y-\left(\sum X\right)\left(\sum Y\right)}{\sqrt{\left\{n \sum X^{2}-\left(\sum X\right)^{2}\right\}\left\{n \sum Y^{2}-\left(\sum Y\right)^{2}\right\}}}
$$

2. Regresi sederha, dengan rumus:

$$
\mathrm{Y}=\mathrm{a}+\mathrm{b}_{1} \mathrm{X}_{1}
$$

dimana :

$\mathrm{Y} \quad=$ Subyek dalam variabeldependen yang diprediksikan

a. = harga konstan

b. $=$ koefisien regresi

$\mathrm{X}=$ subyek pada variabel independen

\section{Bertueilaui 5}

Bẹrriegietsi Ganda

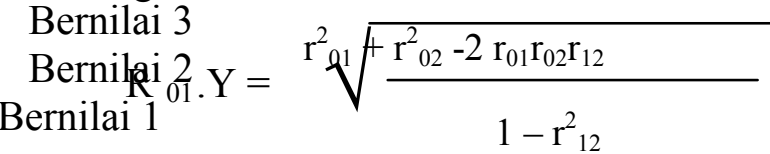

Untuk menggunakan analisis regresi terdapat beberapa prasyarat yang harus dipenuhi yaitu (1) sampel diambil secara acak, (2) variabelnya berhubungan secara linear, dan (3) variabelnya berdistribusi normal atau mendekati normal. Adapun rencana analisis diskriptif dalam penelitian ini adalah sebagai berikut :

\section{Pembuatan Distribusi Frekuensi}

Dalam kelas interval karena sampel yang diambil adalah cukup besar 51 (lima puluh satu) sampel dengan rumus sebagai berikut :

Kelas Interval $=$ $\underline{\text { Skor tertinggi-skor terndah }}+1=\underline{\mathbf{i}}$

Menghitung Skor rata-rata (Mean) masing-masing variabel dengan rumus : $\mathrm{M}=\quad \frac{\sum \mathrm{X}}{\mathrm{n}}$

Menghitung Median masingmasing variabel, dengan rumus

$$
\mathrm{Md}=\mathrm{b}+\mathrm{p}
$$

Keterangan

b. = batas bawah frekuensi

$\mathrm{p}$ = panjang kelas interval

n. = jumlah subyek

$\mathrm{F}=$ Jumlah semua frekuensi diatas frekuensi terbesar 
f. $=$ frekuensi terbesar

\section{Menghitung Modus masing-masing variabel dengan rumus}

$$
\begin{aligned}
& \begin{array}{l}
\mathrm{Md}=\mathrm{b}+\mathrm{p} \\
\text { Keterangan } ;
\end{array} \\
& \mathrm{b} .=\text { batas bawah kelas interval terbesar } \\
& \mathrm{p}=\text { panjang kelas interval } \\
& \mathrm{b}_{1}=\text { frekuensi terbesar dikurangi } \\
& \quad \text { frekuensi dibawahnya } \\
& \mathrm{b}_{2}=\text { frekuensi terbesar dikurangi } \\
& \text { frekuensi diatasnya }
\end{aligned}
$$

\section{Menghitung Standar deviasi skor} masing-masing variabel dengan rumus ; $\sum \mathrm{f}(\mathrm{X}-\mathrm{Xr})^{2}$

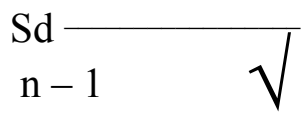

dimana :

Sd $\quad=$ Standard Deviasi

$\mathrm{Xr}=$ Skor Rata - Rata

$\mathrm{n}=$ Jumlah Responden

$\sum \mathrm{Fx} \quad=$ Jumlah Skor Variabel

Membuat Histogram, semua variabel penelitian setelah di analisa datanya dibuat histogram/grafiknya

\section{Uji Hipotesis}

\section{Hipotesis Pertama}

Ho :Tidak Terdapat pengaruh motivasi terhadap kepuasan kerja.

H1 :Terdapat pengaruh motivasi terhadap kepuasan kerja.

$\mathrm{H}_{\mathrm{o}} \quad: \rho_{\mathrm{Y}-1}=0$

$\mathrm{H}_{1}: \rho_{\mathrm{Y}-1}>0$

Menghitung statistik untuk korelasi, dengan menggunakan rumus sebagai berikut :

$$
\mathrm{r}_{\mathrm{xy}}=\frac{\mathrm{n} \sum \mathrm{XY}-\left(\sum \mathrm{X}\right)\left(\sum \mathrm{Y}\right)}{\sqrt{\left.\left\{\mathrm{n} \sum \mathrm{X}^{2}-\left(\sum \mathrm{X}\right)^{2}\right\}\left\{\mathrm{n} \sum \mathrm{Y}^{2}-\sum \mathrm{Y}\right)^{2}\right\}}}
$$

Untuk mengetahui keberartian
signifikasi hubungan antar dua
variabel, dilakukan t tes dengan menggunakan rumus sebagai berikut :

$$
t=\frac{R V n-2}{V 1-r^{2}}
$$

Selanjutnya menghitung regresi sederhana, dengan rumus:

$\mathrm{Y}=\mathrm{a}+\mathrm{b}_{1} \mathrm{X}_{1}$

Menghitung (kontribusi) determinasi variabel $\mathrm{X}_{1}$ terhadap $\mathrm{Y}$ dengan rumus : $\mathrm{D}=\mathrm{r}^{2}{ }_{1 \mathrm{y}} \mathrm{X} 100 \%$

rumus di atas dikutip dari buku Metodologi Penelitian (Benny Gunawan, 2001). Selanjutnya guna mempermudah penghitungan dilakukan dengan alat Bantu computer SPSS 10.0.

4.1. kepegawaian BKP5K, Jumlah pegawai pada Badan Ketahanan Pangan Pelaksana Penyuluhan Pertanian, perikanan dan Kehutanan adalah 282 orang, yang terdiri dari 14 orang pegawai struktural dan 268 orang pegawai fungsional, pegawai fungsional yang ada terdiri dari 209 orang penyuluh pertanian, 20 orang penyuluh perikanan, 14 orang penyuluh peternakan dan 25 orang penyuluh kehutanan.

Badan Ketahanan Pangan Pelaksana Penyuluhan Pertanian Perikanan dan Kehutanan, adalah lembaga teknis daerah, walaupun secara organisasi adalah lembaga struktural, 
akan tetapi sebagian besar pegawainya adalah tenaga fungsional yaitu para penyuluh, yang terdiri dari penyuluh pertanian, penyuluh peternakan, penyuluh perikanan maupun penyuluh kehutanan baik yang bertugas di Badan Ketahanan pangan Pelaksana Penyuluhan Pertanian Perikanan dan Kehutanan (BKP5K), Balai Penyuluhan Pertanian Perikanan (BP3K) maupun tenaga yang ada di daerah binaan.

Dari data yang ada obyek yang akan diteliti adalah sebanyak 209 orang yaitu penyuluh pertanian baik penyuluh Pegawai Negeri Sipil maupun penyuluh yang berstatus tenaga kontrak (Non Pegawai Negeri Sipil), Analisa Deskriptif Data Penelitian

\section{Karakteristik Pegawai}

Untuk melengkapi ataupun memperkuat analisa tentang pengaruh dari variabel-variabel yang diteliti, maka disajikan berbagai karakteristik pegawai khususnya para penyuluh pertanian yang menjadi responden dalam penelitian, sebagai berikut :

a. Karakteristik pegawai berdasarkan Golongan pangkat

Dari keseluruhan jumlah responden yang diteliti diperoleh hasil karakteristik responden menurut golongan yakni responden yang terbanyak mempunyai golongan 2 sebesar 1 orang $(52,38 \%)$ diikuti oleh responden golongan 3 yakni 25 orang $(30,00 \%)$, dan responden golongan 4 sebesar 10 orang $(17,62 \%)$. Sedangkan responden tenaga kontrak (THL-TB) adalah 16 orang. Uraian mengenai hal ini disajikan pada Tabel 2. Berikut

Tabel 2. Karakteristik Penyulu Berdasarkan Pangkat golongan

\begin{tabular}{|c|l|c|r|}
\hline No & \multicolumn{1}{|c|}{ Pangkat/Gol } & Jumlah & Prosentase \\
\hline 1 & Pengatur T.I/ II/d & 1 & 1.96 \\
\hline 2 & Penata Muda/ III/a & 2 & 3.92 \\
\hline 3 & Penata Muda Tk.I/ III/b & 9 & 17.65 \\
\hline 4 & Penata/III/c & 9 & 15.69 \\
\hline 5 & Penata Tk.I/III/d & 5 & 9.80 \\
\hline 6 & Pembina/IV/a & 10 & 19.61 \\
\hline 7 & Honorer (THL-TB) & 16 & 31.37 \\
\hline & Jumlah & 51 & 100.00 \\
\hline
\end{tabular}

Dari data diatas dapat disimpulkan bahwa dari sisi golongan/pangkat penyuluh pertanian secara akumulatif didominasi oleh penyuluh golongan III yaitu sebanyak 24 orang atau $47,6 \%$, dengan demikian para penyuluh perikanan masih dimungkinkan untuk meningkatkan kariernya ke jenjang lebih tinggi.

a. Karakteristik Pegawai Berdasarkan Tingkat Pendidikan

Rincian hal ini disajikan pada

Tabel 3. Berikut: 
Tabel 3. Karakteristik Pegawai Berdasarkan Pendidikan

\begin{tabular}{|c|l|c|c|}
\hline No & \multicolumn{1}{|c|}{ Uraian } & Jumlah & Prosentase \\
\hline 1 & SLTA & 13 & 25.49 \\
\hline 2 & Diploma III & 14 & 27.45 \\
\hline 3 & Diploma IV & 2 & 3.92 \\
\hline 4 & Sarjana (S1) & 22 & 43.14 \\
\hline & Jumlah & 51 & 100.00 \\
\hline
\end{tabular}

Dari data diatas terlihat bahwa sebagian besar tingkat pendidikan penyuluh adalah sarjana 22 orang atau 43,14\% dan Diploma IV sebanyak 2 orang (3,92\%), yaitu penyuluh pertanian ahli, yang pangkat puncaknya dapat mencapai IV/c, dengan demikian kemungkinan penyuluh masih potensial untuk mengembangkan kariernya.

\section{Diskripsi Data Setiap Variabel Motivasi}

Data motivasi yang berasal dari kuesioner ini menyebar dari skor terendah 63 dan tertinggi 83. Dengan demikian, rentangan skor yang muncul adalah sebesar 20 dari 63 sampai 83 . Selanjutnya dilakukan analisis dan hasilnya diperoleh rata-rata sebesar 73,71 dengan tingkat standar deviasi sebesar 3,757 dimana jumlah responden yang diukur sebanyak 51. Banyak kelas yang ditetapkan dalam penelitian ini terdiri dari 7 kelas dengan panjang kelas 3. Selanjutnya distribusi frekuensi skor Motivasi menurut aturan Sturges disajikan pada tabel berikut :

Tabel 4. Distribusi Skor Motivasi

\begin{tabular}{|c|c|c|c|c|}
\hline No & $\begin{array}{c}\text { Interval } \\
\text { Kelas }\end{array}$ & $\begin{array}{c}\text { Frekuensi } \\
\text { Absolut }\end{array}$ & $\begin{array}{c}\text { Frekuensi } \\
\text { Relatif (\%) }\end{array}$ & $\begin{array}{c}\text { Frekuensi } \\
\text { Kumulatif (\%) }\end{array}$ \\
\hline 1 & $63-65$ & 5 & 9.80 & 9.80 \\
\hline 2 & $66-68$ & 4 & 7.84 & 17.65 \\
\hline 3 & $69-71$ & 5 & 9.80 & 27.45 \\
\hline 4 & $72-74$ & 16 & 31.37 & 58.82 \\
\hline 5 & $75-77$ & 7 & 13.73 & 72.55 \\
\hline 6 & $78-80$ & 9 & 17.65 & 90.20 \\
\hline 7 & $81-83$ & 5 & 9.80 & 100.00 \\
\hline \multicolumn{7}{|r}{ Jumlah } & & 51 & 100.00 & \\
\hline
\end{tabular}

Dari tabel tersebut dapat dilihat bahwa sebanyak 16 responden $(31,37 \%)$ berada pada kelompok rata-rata, 14 responden $(27,44 \%)$ berada pada kelompok di bawah rata-rata dan 21 responden $(41,18 \%)$ berada di atas ratarata. Dari data tersebut terlihat bahwa
Motivasi Kerja para pegawai di Badan Pelaksana Penyuluhan Pertanian Perikanan dan Kehutanan sudah cukup baik meskipun harus ditingkatkan, hal ini terlihat dari jawaban responden tentang Motivasi dimana 37 responden atau $72,55 \%$ jawabannya berada pada 
skor rata-rata dan di atas rata-rata. Gambaran lebih jelas mengenai distribusi skor data variabel Motivasi ini disajikan pada histogram berikut :

\section{Grafik Histogram Motivasi}

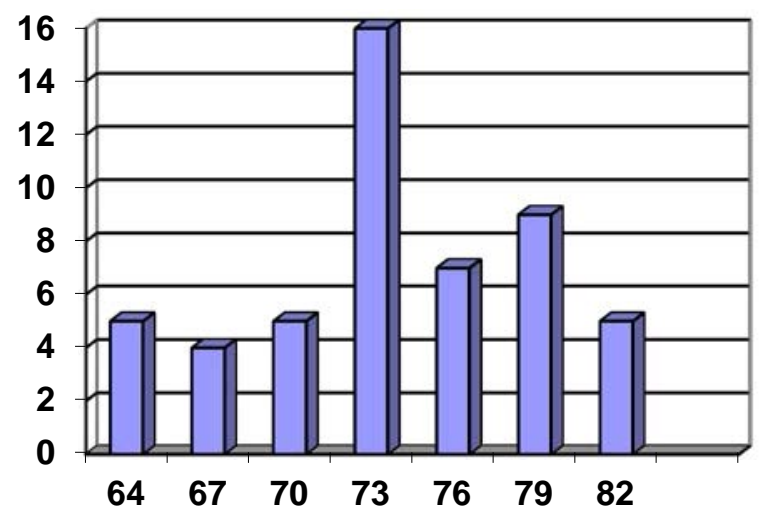

Std. Dev : 3,757

Mean $\quad: 75,92$

Gambar diatas menginformasikan bahwa skor data yang diperoleh cenderung menyebar. Skor tengah cenderung lebih tinggi dari skor atas dan bawah. Gambaran ini terlihat dari histogramnya yang cenderung memiliki angka tengah yang lebih tinggi. Hal ini berarti bahwa data skor Variabel Motivasi cenderung sudah baik, meskipun masih perlu upaya untuk lebih meningkat lagi.

\section{Kepuasan Kerja}

Data Kepuasan Kerja yang berasal dari kuesioner ini menyebar dari skor terendah 65 dan tertinggi 84 . Dengan demikian, rentangan skor yang muncul adalah sebesar 19 dari 65 sampai 84. Selanjutnya dilakukan analisis dan hasilnya diperoleh rata-rata sebesar 73,71 dengan tingkat standar deviasi sebesar 3,870 dimana jumlah responden yang diukur sebanyak 51 . Banyak kelas yang ditetapkan dalam penelitian ini terdiri dari 7 kelas dengan panjang kelas 3. Selanjutnya distribusi frekuensi skor Kepuasan Kerja menurut aturan Sturges disajikan pada tabel berikut

Tabel 5. Distribusi skor kepuasan kerja

\begin{tabular}{|c|c|c|r|r|}
\hline No & $\begin{array}{c}\text { Interval } \\
\text { Kelas }\end{array}$ & $\begin{array}{c}\text { Frekuensi } \\
\text { Absolut }\end{array}$ & $\begin{array}{c}\text { Frekuensi } \\
\text { Relatif (\%) }\end{array}$ & $\begin{array}{c}\text { Frekuensi } \\
\text { Kumulatif (\%) }\end{array}$ \\
\hline 1 & $65-67$ & 4 & 7.84 & 7.84 \\
\hline 2 & $68-70$ & 4 & 7.84 & 15.69 \\
\hline 3 & $71-73$ & 5 & 9.80 & 25.49 \\
\hline 4 & $74-76$ & 17 & 33.33 & 72.82 \\
\hline 5 & $77-79$ & 7 & 13.73 & 88.24 \\
\hline 6 & $80-82$ & 8 & 15.69 & 100.00 \\
\hline 7 & $83-85$ & 6 & 11.76 & \\
\hline \multicolumn{2}{r|}{} \\
\hline
\end{tabular}


Dari tabel tersebut dapat dilihat bahwa sebanyak 17 responden (33,33\%) berada pada kelompok ratarata, 13 responden $(25,28 \%)$ berada pada kelompok di bawah rata-rata dan 21 responden $(41,18 \%)$ berada di atas rata-rata. Dari data tersebut terlihat bahwa Kepuasan Kerja para pegawai di Badan Pelaksana Penyuluhan Pertanian Perikanan dan Kehutanan sudah cukup baik meskipun harus ditingkatkan, hal ini terlihat dari jawaban responden

\section{Grafik Histogram Kepuasan Kerja}

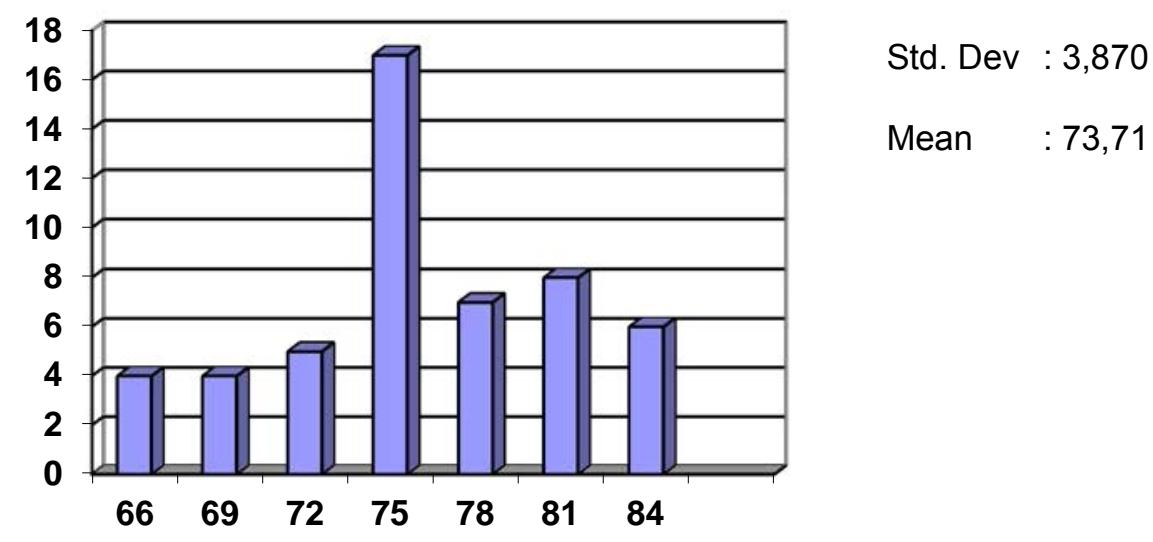

Gambar 5.2 menginformasikan bahwa skor data yang diperoleh cenderung menyebar. Skor tengah cenderung lebih tinggi dari skor atas dan bawah. Gambaran ini terlihat dari histogramnya yang cenderung memiliki angka tengah yang lebih tinggi. Hal ini berarti skor Variabel Kepuasan Kerja cenderung mempunyai distribusi normal.

\section{Pengujian Korelasi} sebagai berikut : tentang Kepuasan Kerja dimana 38 responden atau $74,34 \%$ jawabannya berada pada skor rata-rata dan di atas rata- rata. Gambaran lebih jelas mengenai distribusi skor data variabel Kepuasan Kerja ini disajikan pada histogram berikut :

Guna mengetahui secara detail hubungan antara variabel Motivasi dan Pengembangan Karier dengan Kepuasan Kerja maka perlu dilakukan pengujian dengan menggunakan model pengujian korelasi. Hasil pengujian korelasi adalah

Tabel 6. Hasil Pengujian Korelasi

\begin{tabular}{|l|c|}
\hline & Kepuasan Kerja \\
\hline Motivasi & $\mathbf{0 , 8 5 2}$ \\
\hline
\end{tabular}


Hasil pengolahan data tersebut menjelaskan bahwa :

1. Hubungan antara Motivasi dan Kepuasan Kerja pada Badan Ketahanan Pangan Pelaksana Penyuluhan Pertanian Perikanan dan Kehutanan dengan nilai korelasi sebesar 0.852. Dengan demikian terdapat hubungan positif sangat kuat antar variabel, artinya bila variabel motivasi ditingkatkan maka akan diikuti dengan peningkatan Kepuasan Kerja pada Badan Ketahanan
Pangan Pelaksana Penyuluhan Pertanian Perikanan dan Kehutanan.

2. Berdasarkan hasil pengolahan data terhadap hubungan antara Motivasi terhadap Kepuasan Kerja pada Badan Ketahanan pangan Pelaksana Penyuluhan Pertanian Perikanan dan Kehutanan, maka perlu dilakukan Analisis summery untuk mengetahui hubungan secara bersama-sama antara Motivasi $\left(\mathrm{X}_{1}\right)$ terhadap Kepuasan Kerja (Y) Hasil pengolahan dengan analisis summery tersebut adalah sebagai berikut

Tabel 7. Hasil Analisis Summery

\begin{tabular}{|c|c|c|c|}
\hline Model & $\mathbf{R}$ & Adjusted R Square & Std Error of The Estimate \\
\hline 1 & $\mathbf{0 , 8 5 2}$ & $\mathbf{0 , 7 9 3}$ & $\mathbf{1 , 5 5 2}$ \\
\hline
\end{tabular}

Berdasarkan hasil analisis summery tersebut diperoleh nilai $\mathrm{R}$ sebesar 0,892. Hal ini berarti terdapat hubungan positif yang sangat kuat antara Motivasi $\left(\mathrm{X}_{1}\right)$ terhadap Kepuasan Kerja pada Badan Ketahanan Pangan Pelaksana Penyuluhan Pertanian Perikanan dan Kehutanan. berarti variasi peningkatan atau penurunan variabel Kepuasan Kerja pada BKP5K dapat dijelaskan oleh Motivasi $\left(\mathrm{X}_{1}\right)$ sebesar $89,2 \%$ maka faktor lain di luar variabel tersebut sebesar 10,8\%.Gambar hubungan antar variabel dijelaskan sebagaimana berikut ini :

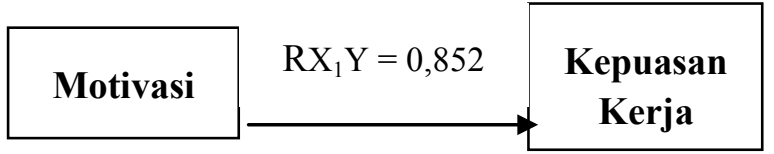

Gambar 9

Hubungan Variabel Independen dan Dependen

Berdasarkan skema di atas, baik Motivasi kerja maupun Pengembangan Karier memiliki korelasi positif terhadap Kepuasan Kerja pada Badan Pelaksana Penyuluhan Pertanian Perikanan dan Kehutanan. Selanjutnya dilakukan uji regresi guna menguji hipotesis terhadap kedua variabel yang diteliti, dan setelah dilakukan pengolahan diperoleh hasil pengujian sebagai berikut :

Tabel 8. Hasil Uji Regresi

\begin{tabular}{|l|c|c|c|c|c|}
\hline \multirow{2}{*}{} & \multicolumn{2}{|c|}{$\begin{array}{c}\text { Unstandardized } \\
\text { Coefficients }\end{array}$} & $\begin{array}{c}\text { Unstandardize } \\
\text { d Coefficients }\end{array}$ & \multirow{2}{*}{ Sig } & \\
\cline { 2 - 4 } & B & Std Error & Beta & & \\
\hline Konstanta & 4,995 & 3,146 & & 1,588 & 0,114 \\
\hline Motivasi & 0,320 & 0,060 & 0,355 & 5,301 & 0,000 \\
\hline
\end{tabular}




$$
\begin{gathered}
\mathrm{Y}=\mathrm{a}+\mathrm{b}_{1} \mathrm{X}_{1} \\
\operatorname{dimana} \\
\mathrm{Y}=4,995+0,320 \mathrm{X}_{1}
\end{gathered}
$$

Hasil pengolahan data dengan uji regresi di atas dapat dijelaskan sebagai berikut :

1. Hasil constanta menunjukkan nilai sebesar 4,995. Dengan demikian, variabel Kepuasan Kerja pada BKP5K murni tanpa adanya pengaruh oleh variabel Motivasi sebesar 4,995.

2. Nilai regresi $b_{1}$ (Motivasi) didapat sebesar 0,320. Dengan demikian, terdapat kontribusi oleh Variabel Motivasi, yang berarti bila BKP5K meningkatkan efektivitas Motivasi 1 skor maka memberikan pengaruh terhadap peningkatan Kepuasan Kerja pada Badan BKP5K sebesar 0,320 skor.

\section{Uji Hipotesis Individu (Uji t )}

Dengan kaidah :

$$
\text { hitung }>\mathrm{t}_{\text {tabel }}
$$

$\left(\mathrm{H}_{0}\right)$ ditolak dan $\left(\mathrm{H}_{\mathrm{a}}\right)$ diterima, maka ada hubungan antara X terhadap Y.

$t_{\text {hitung }}<t_{\text {tabel }} \quad\left(\mathrm{H}_{0}\right)$ diterima tdan $\left(\mathrm{H}_{\mathrm{a}}\right)$ ditolak, maka tidak ada hubungan antara $\mathrm{X}$ terhadap $\mathrm{Y}$.

$$
\alpha=0,05 \text { atau } 5 \%
$$

- Variabel Motivasi

Hasil pengolahan data menunjukkan nilai $t_{\text {hitung }}$ sebesar 5,301 dimana $t_{\text {tabel }}$ sebesar 1,96. Dengan demikian $t_{\text {hitung }}$ $5,301>\mathrm{t}_{\text {tabel }} 1,96$, maka $\left(\mathrm{H}_{0}\right)$ ditolak dan $\left(\mathrm{H}_{\mathrm{a}}\right)$ diterima artinya ada hubungan antara variabel Motivasi $\left(\mathrm{X}_{1}\right)$ dengan Kepuasan Kerja (Y) pada BKP5K. Sedangkan probabilitas hasil sebesar 0,000 atau $0 \%$ dimana nilai $\alpha=0,05$ atau 5\% dengan demikian probabilitas di bawah nilai alpha, berarti variabel motivasi $\left(\mathrm{X}_{1}\right)$ signifikan terhadap Kepuasan Kerja pada BKP5K

\section{KESIMPULAN}

Berdasarkan penelitian yang dilakukan mengenai pengaruh Motivasi terhadap Kepuasan Kerja BKP5K dan hasil pengolahan data terhadap variabel bebas Motivasi $\left(\mathrm{X}_{1}\right)$ serta variabel terikat Kepuasan Kerja (Y) pada BKP5K dapat diambil beberapa kesimpulan sebagai berikut : :Hasil uji t variabel Motivasi $\left(\mathrm{X}_{1}\right)$ terhadap Kepuasan Kerja (Y) menunjukkan bahwa nilai $t_{\text {hitung }}$ sebesar 5,301 dan $t_{\text {tabel }}$ sebesar 1,96 pada level significants 0,05 dan probabilitas 0,000 . Hal ini berarti $\mathrm{t}_{\text {hitung }}=5,301>\mathrm{t}_{\text {tabel }}=1,96$, maka $\mathrm{H}_{0}$ ditolak dan $\mathrm{H}_{\mathrm{a}}$ diterima, berarti terdapat pengaruh Motivasi $\left(\mathrm{X}_{1}\right)$ terhadap Kepuasan Kerja (Y) BKP5K.

Koefisien korelasi Motivasi $\left(\mathrm{X}_{1}\right)$ terhadap Kepuasan Kerja (Y) pada BKP5K adalah 0,852 sehingga diperoleh nilai koefisien determinasi sebesar 0,852 atau 85,2 \%. Hal ini berarti bahwa faktor-faktor lain di luar yang tidak diteliti namun berpengaruh juga adalah sebesar $10,8 \%$.

\section{Saran}

Untuk dapat lebih meningkatkan Kepuasan Kerja pada Badan Pelaksana Penyuluhan Pertanian Peternakan Perikanan dan Kehutanan ditinjau dari sudut motivasi maka disarankan agar motivasi kerja para pegawai dapat meningkat perlu diwujudkan peningkatan kebutuhan dari para 
pegawai. Pemenuhan terhadap kebutuhan para pegawai yang bekerja pada Badan Pelaksana Penyuluhan Pertanian Peternakan Perikanan dan Kehutanan maka akan meningkatkan Kepuasan Kerja dari Badan Pelaksana Penyuluhan Pertanian Perikanan dan Kehutanan. Peningkatan motivasi juga dapat dilakukan melalui perbaikan sistem manajemen melalui perbaikan sarana, prasarana kerja dan sistem yang berlaku. Dengan adanya perbaikan sarana, prasarana kerja dan sistem kerja maka tidak mustahil para pegawai semakin memotivasi diri untuk meningkatkan produktivitas dirinya

\section{DAFTAR PUSTAKA}

Bernardin, H.John and Russel, Joice E.A., 1998. Human Resources Frameworks For General Manager New York; John Wiley \& Sons,Inc (1962:108).

Benny Gunawan, 2001 Metodologi Penelitian. Program Pasca Sarjana Magister Manajemen. Universitas Satyagama Jakarta
Budi W. Soetjipto. (et.al). 2002. Paradigma Baru

Buchari Zainun (1984:22-23) Sumberdaya Manusia, Amara Books, Jogyakarta

Mason Haire dan Keith Davis dan John W. Newstroom, 1989.Human Resources and Personal Management. Third Edition. MCGraw Hill International Edition 